\title{
FACTOR ANALYSIS AND COMPARISON BETWEEN DIGITAL MARKETING AND TRADITIONAL MARKETING
}

\author{
Jushya Gandotra \\ Delhi Public School, R. K. Puram \\ DOI: 10.46609/IJSSER.2021.v06i07.031 URL: https://doi.org/10.46609/IJSSER.2021.v06i07.031
}

\begin{abstract}
This research paper signifies the marketing dichotomy between digital and traditional marketing approaches which are adopted by several business organizations. This research seemed at the dynamic nature of marketing as the main objective of the marketing is to produce products and do their marketing so that both buyers and sellers get benefitted. It is however the major work of the market to promote the finished product. Marketing however is no more a simple task nowadays. Consumers are becoming smarter and choosy at the time of purchasing products. So marketing needs to be more innovative as well as attractive so that people get molded. In this research paper, the main focus is given to understand the difference between the traditional and digital forms of marketing approach and to get the result of that. The current paper signifies several factors that influenced directly or indirectly the marketing approach of both traditional and digital to get the result. However, the secondary research findings are compiled and analyzed in a detailed manner during the research process. The findings add the implementation of the factors in both the marketing approach. The conclusion defines all the aspects concisely that are the similarities and differences of these approaches.
\end{abstract}

Keywords- Digital marketing, Traditional Marketing

\subsection{Introduction}

People think that marketing is the form of advertising for sale. Moreover, marketing is nothing but everything that a company does to attract customers and to maintain a good salesmanship relation with them. Several terms are used to attract such as writing thank you letters, meeting with old customers and making everyone a warm welcome, asking them for coffee or tea, etc. are some examples. However, the actual aim of marketing is to provide and make people aware of the company's products and services, which may increase the company's profit maximization. 
The oldest and natural form of marketing is the marketing done by word of mouth, in which the customer is to be convinced and the customer himself/ herself conveys their experiences about a product, service, or brand in their day-to-day communication with others. These interactions can of course have a positive effect on others, and they become influenced. Though in some cases this may lead to negative impacts if the customer experience is bad. In simple words marketing is all about what a company does to place its product and service if the customer has a bad experience. It includes the coordination of identification, selection of a distribution channel to reach the customer's place, and development and implementation of a promotional strategy (Bala 2018).

\section{However, two types of marketing approaches exist such as}

1. Traditional Marketing.

2. Digital Marketing.

\section{Traditional Marketing}

In traditional marketing companies directly target customers and have face-to-face interaction with them. They have found customers through several means and mediums such as; newspapers, Magazines, Billboards, TV Ads, Radio, Brochures, and other printed materials, etc.

\section{Digital Marketing}

Digital Marketing mainly depends on the internet. In this type of marketing promotions of products are done through several electronic materials. Phillip Kotler is the father of Digital Marketing. For example- advertising through the internet, in social media platforms, mobile phones, etc.

\section{Differences between Traditional Marketing and Traditional Marketing}

The difference based on usage- Digital marketing and traditional marketing are similar to some extent but it is done through the digital medium so-called the internet. The traditional method of marketing helps to get in contact with customers belonging to the old generation as in this method companies try to tie up with all customers personally. On the other hand, digital marketing makes use of digital means such as computers, tablets, smartphones, laptops, etc. It is an interactive means of reaching local customers as well as global customers in a company. This data is easily available and immediately shown, that's why it is much easier for the company to evaluate. 
International Journal of Social Science and Economic Research

ISSN: 2455-8834

Volume:06, Issue:07 "July 2021"

The difference on the basis of goal achievement - Nowadays social media is something where almost everyone is available, especially the young generation. Affiliate marketing is happening through digital marketing, it is a form of digital marketing. In traditional marketing hard copy material is available wherein in digital marketing only soft copy is available such as pdf documents etc. There are so many ways of marketing the products and techniques. However traditionally greater exposure is quite possible to reach local audiences while digital marketing companies can reach global customers too. Production becomes meaningless if sales aren't high, so marketing is quite important. Digital marketing as well as traditional marketing provides clients and customers in their own way. It is quite difficult to distinguish between online marketing vs. traditional marketing as both are important equally in different situations (Yasmin 2015).

The difference on the basis of employment - A wise entrepreneur will set aside a separate budget for marketing. The main problem arises when a huge part of the young generation is acquainted with online marketing, shopping, and all, on the contrary, a chunk of the population who ignore the internet cannot get services. In traditional marketing, a large scale of the population is appointed in the marketing sector but in digital marketing, there is no need for so much employment. Though it saves company's expenditure on the other hand it reduces employment facilities.

The difference on the basis of advertisements - People are buying newspapers for news not for advertisements, they buy magazines for the content it has not to read ads and advertisements so it can be said that in the traditional method of marketing mostly the advertisements are ignored. While in digital marketing, there is an option to either anyone who wants to see ads or not. Sometimes irritating ads are very annoying on both platforms. So the battle between traditional and digital marketing is difficult to resolve. Very much due to the real-time results of online marketing, instant publicity can be gained.

Some companies which are using a traditional form of marketing - Small scale industries that have limited marketing budgets are mainly using Traditional forms of marketing in their business such as the companies of rural areas, small city areas, etc. Besides that, some reputed companies use the traditional form of marketing namely- Burger King, famous magazines for women, billboards of coca-cola, zoo by Vodafone, Hog magazine, etc.

Some Companies which are using Digital Form of Marketing - The small to large scale industries are using a digital approach of marketing through social media, email marketing, and digital advertising. Recently so many online business firms are using digital forms of marketing to expand their business. 


\section{International Journal of Social Science and Economic Research}

ISSN: $2455-8834$

Volume:06, Issue:07 "July 2021"

\subsection{Literature Review}

The 21st century is the beginning of a digital trend, everything is getting involved in the digital world. Digital Marketing is gaining popularity over time and somehow it is substituting Traditional marketing but not completely.

As per the views of Todor (2016), Digitalisation is the key aspect of the modern world. Everyone prefers things over the internet rather than visiting the real market. We cannot say that the Digital market has completely taken over the traditional market, but somehow it has a greater reach of audience than the previous ones. In terms of communication, distribution, and engagements of customers, digital marketing has taken more than the traditional method.

Salehi et al., (2012), Says that companies have to pay a huge amount to advertise their products. Small companies and start-ups find it difficult to showcase their products and services among these huge investors. Digital marketing can be helpful for these local entrepreneurs to advertise their brands through less investment. Even studies have shown that these days people are more interested in personalized products over the internet.

Many researchers suggest the comparison between marketing and e-marketing. In general marketing or traditional marketing, the company approaches the customers directly to advertise and sell their products or avail services whereas in Digital marketing the company targets a set of audience and directly communicates with them online or social networking platforms. Digital marketing provides a scope to study the audience, demand, and supply of the product. It is one of the cheapest as well as effective means of marketing. Digital platforms like Facebook, Instagram, etc... Can be utilized to engage the customer and create leads for the products. Mirzaei et al., (2012) state that digital marketers can track marketing growth. In a traditional marketing channel, it is difficult to keep a track of the customers. However, it has become easier to understand the customer mindset through analytics, which keeps records of reach, lead generation, conversion, and even has the records of existing customers. This entire scenario helps to target the audience that would buy the product or develop the products to reach more leads in the future. However, we cannot rely on digital marketing completely.

According to the views of Bayan, (2014), Traditional marketing has its own charm that can never be replaced by online marketing. But merging both the marketing approaches would get a tremendous result for the company. Blending the traditional market principle with modern technology would benefit the marketers to bring the customers into the organization. With the help of online marketing interaction, the company can gain real market customers. In fact it is a broader concept that would help the traditional market companies to expand their business across 
International Journal of Social Science and Economic Research

ISSN: 2455-8834

Volume:06, Issue:07 "July 2021"

the world. Therefore digital marketing would be effective and well collaborate with traditional marketing to gain more popularity of the brand and products.

\subsection{Research Question}

Q. What is the comparison between traditional and digital marketing using different factors?

\subsection{Research Methodology}

The research methodology is the process that showcases the methods used in the research paper to justify the findings. The methodology includes the steps, techniques, and procedures for data collection and data analysis (Park et al., 2020). In the research paper, the researcher uses the qualitative research methodology for collecting the data. The data relating to traditional marketing and digital marketing are collected through secondary data collection methods. The researcher used different parameters such as targeting of customers, decision making of the marketing, leadgeneration, customer experience to provide an understanding of the differences between traditional marketing and digital marketing ( Mandal,2017). The researcher uses a secondary method to present the qualitative and quantitative nature of the marketing strategies used in these marketing. The data collected are reliable and valid in serving the purpose of the research.

\subsection{Research Paradigm}

The research paradigm is the common belief of the researcher that helps to develop the findings of the present research. This helps to identify and understand the research question thoroughly. From the past findings that have been discussed in the literature review, the researcher could get inferences about the differences (Nicolas,2020). Paradigm provides a mindset for the research topic. The traditional marketing concept is established on the basis ofthe trustworthiness of the customers. However, digital marketing has significance in gaining customers' trust as well as losing the trust as in digital mode customers check feedback of the previous buyer before buying the products (Hammou, 2020). This paradigm was developed to understand the reality of digital market scenarios. In this research, interpretivism is used to explore the thoughts of customers, society on preferring digital marketing instead of traditional marketing. This provides a comprehensive and comparative analysis for the findings and results interpretation.

\subsection{Research Philosophy}

Every problem, every question needs a path to find its answers. One cannot reach the destination without knowing the path to walk in. Similarly, it cannot be concluded that traditional marketing 
International Journal of Social Science and Economic Research

ISSN: 2455-8834

Volume:06, Issue:07 "July 2021"

is better than digital marketing or vice versa. In order to understand the difference, the research philosophy is important (Pandey,2021). The research philosophy promotes the researcher towards the direction of the research. It would address the engagements of customers in both the form of marketing and show return on investment data from the past findings. Research philosophy provides a synopsis about the effectiveness of having traditional marketing and digital marketing in any organization. It shows that these days companies are adopting the digital model in their general marketing strategies. The research philosophy helps to generate hypotheses and generate ideas regarding the findings.

\subsection{Research Design}

A research design is a method used in the research paper that outlines how the data are collected, measured, and analysed to formulate final findings or interpret the results. It explains the connection between the theories and statistical findings. The research design helps in a detailed analysis of the data collected during the research.

Concerning the following study, the descriptive design would be appreciated that would provide the difference present in both forms of marketing in a rational manner (Newman,2020).In traditional marketing, it is difficult to understand the exact mechanism that resulted in lead generation. Nevertheless, digital marketing presents a real analytical experience for the customer. Therefore the descriptive method would provide justice to mark the difference between them.

\subsection{The research approach}

The research approach is the process through which research design is planned. The research approach sets guidelines for the source of data collection, the method of interpretation. In this research secondary data is collected regarding traditional marketing and digital marketing. The interpretivism and descriptive method are utilized in the analysis of the data to generate results. All the data collected are thoroughly evaluated and filtered to make available only the relevant data for the findings of the results. The data was collected from authentic sources like google scholars, journals, and articles regarding the parameters of marketing done through digital mode and marketing things done through traditional methods. The relevant data are separated using the inductive and deductive approaches.

\subsection{Data Collection}

Data collection is the process through which the information is gathered for the research findings. Basically, the data is collected through the primary source and secondary source. In the primary method, the data is collected directly whereas in the second method the data is obtained 
from the previous findings. In this research, the secondary source of data is collected due to the nature of the research. It is not practical to collect first-hand data as there is a huge market base and there are unlimited companies. Doing so would take years and years to collect all the data. So, the secondary source would be suitable for studying the differences between traditional marketing and digital marketing. Therefore, the sample for this research has been taken from different sources such as google scholar, journal articles, etc. Out of which 4-5 relevant articles were selected (discussed in the literature review section).

\subsection{Data Analysis}

The following information is derived from the data collection. This provides a comparative analysis between traditional marketing and digital marketing-

\begin{tabular}{|c|c|c|}
\hline Factors & Traditional Marketing & Digital Marketing \\
\hline Return on Investment & $\begin{array}{l}\text { In traditional marketing, the } \\
\text { return on investment means a } \\
\text { profit earned over the sale of a } \\
\text { particular product or marketing } \\
\text { strategy. A } 7 \% \text { ROI is } \\
\text { considered a good return rate in } \\
\text { the corporate world. (López } \\
\text { 2019) }\end{array}$ & $\begin{array}{l}\text { In Digital Marketing the } \\
\text { return on investment is } \\
\text { calculated to evaluate the } \\
\text { amount of revenue generated } \\
\text { from the digital marketing or } \\
\text { campaign. Here ROI presents } \\
\text { the profit and loss of the } \\
\text { investment. (López 2019) } \\
\text { ROI- }\end{array}$ \\
\hline
\end{tabular}


International Journal of Social Science and Economic Research

ISSN: 2455-8834

Volume:06, Issue:07 "July 2021"

\begin{tabular}{|l|l|l|l|}
\hline & & & Email marketing- 42.5\% \\
Social media Ad-37\% \\
Paid Ad- 36\%
\end{tabular}


International Journal of Social Science and Economic Research

ISSN: 2455-8834

Volume:06, Issue:07 "July 2021"

\begin{tabular}{|c|c|c|}
\hline & $\begin{array}{l}\text { marketing, marketers use } \\
\text { traditional methods such as } \\
\text { magazines, newspapers, and } \\
\text { commercial ads to generate } \\
\text { interest among the customers. It } \\
\text { is difficult to measure the lead } \\
\text { rates as it does not create any } \\
\text { direct contact between the buyer } \\
\text { and seller. }\end{array}$ & $\begin{array}{l}\text { Here the marketers approach } \\
\text { the customers through a direct } \\
\text { medium such as Facebook, } \\
\text { Instagram, cold emails } \\
\text { (Gaitniece 2018) } \\
\text { Whenever companies raise the } \\
\text { overall amount of content } \\
\text { marketing between } 10 \text { towards } \\
\text { 15, they notice a } 55 \text { percent } \\
\text { boost in inquiries. LinkedIn } \\
\text { prospect creation proved } \\
\text { productive overall } 65 \text { percent } \\
\text { of all B2B firms. } 79 \text { percent of } \\
\text { most advertising inquiries are } \\
\text { not transactions. }\end{array}$ \\
\hline Conversion & $\begin{array}{l}\text { It is difficult to convert the } \\
\text { customer from the traditional } \\
\text { method. However, companies }\end{array}$ & $\begin{array}{l}\text { Conversion is possible in } \\
\text { digital marketing only; } \\
\text { Conversion is getting the }\end{array}$ \\
\hline
\end{tabular}


International Journal of Social Science and Economic Research

ISSN: 2455-8834

Volume:06, Issue:07 "July 2021"

\begin{tabular}{|c|c|c|}
\hline & $\begin{array}{l}\text { use discount coupons to make } \\
\text { buyers visit the shop. }\end{array}$ & $\begin{array}{l}\text { customer to the final } \\
\text { destination of actually buying } \\
\text { the item. } 2-5 \text { of the conversion } \\
\text { rateis actually a healthy ratio } \\
\text { for the business (Kannan } \\
\text { 2017). }\end{array}$ \\
\hline Engagement & $\begin{array}{l}\text { Customer engagement is purely } \\
\text { dependent upon the marketing } \\
\text { strategies. }\end{array}$ & $\begin{array}{l}\text { Numerous promotional } \\
\text { strategies (networking sites, } \\
\text { SEO, big corporations, etc.) } \\
\text { position as merely engaging } \\
\text { on what the advertiser needs } \\
\text { you to engage on. A } \\
\text { connection between all the } \\
\text { consumer or the company has } \\
\text { sought to introduce merely by } \\
\text { paying enough attention to } \\
\text { anything in any manner. }\end{array}$ \\
\hline Effectiveness & $\begin{array}{l}\text { In terms of effectiveness, } \\
\text { traditional marketing steps one }\end{array}$ & $\begin{array}{l}\text { No doubt digital marketing } \\
\text { has a broader market base, the }\end{array}$ \\
\hline
\end{tabular}


International Journal of Social Science and Economic Research

ISSN: 2455-8834

Volume:06, Issue:07 "July 2021"

\begin{tabular}{|c|c|c|}
\hline & $\begin{array}{l}\text { step behind because it cannot } \\
\text { reach all the customers through } \\
\text { the traditional mode of } \\
\text { marketing. However, it plays a } \\
\text { significant role in sustaining and } \\
\text { retaining the customer. } \\
\text { Traditional method marketing } \\
\text { can grab customer attention for a } \\
\text { long time whereas in digital } \\
\text { marketing a customer gets } \\
\text { diverted easily. }\end{array}$ & $\begin{array}{l}\text { marketing is based on content } \\
\text { creation and feedback } \\
\text { generation. } \\
\text { marketers need to pay more } \\
\text { attention as the wrong steps } \\
\text { can lead to a downgrade of the } \\
\text { market. So the effectiveness } \\
\text { depends upon the organic } \\
\text { growth of the business. }\end{array}$ \\
\hline Tracking & $\begin{array}{l}\text { Tracking in traditional marketing } \\
\text { requires a lengthy process and it } \\
\text { is very time-consuming or we } \\
\text { can say it is quite impossible to } \\
\text { track the customer. }\end{array}$ & $\begin{array}{l}\text { In Digital marketing tracking } \\
\text { could be done easily. Keeping } \\
\text { a record of everything is a } \\
\text { positive point (Melović 2020). } \\
\text { Marketers can check the lead } \\
\text { generation, conversion, and } \\
\text { even how many customers } \\
\text { exited the site. }\end{array}$ \\
\hline
\end{tabular}


International Journal of Social Science and Economic Research

ISSN: 2455-8834

Volume:06, Issue:07 "July 2021"

\begin{tabular}{|c|c|c|}
\hline Targeting & $\begin{array}{l}\text { Target marketing entails } \\
\text { segmenting the whole market } \\
\text { and implementing marketing } \\
\text { with each category in order to } \\
\text { enhance sales volume. In } \\
\text { traditional marketing, the } \\
\text { products are targeted to a general } \\
\text { audience. }\end{array}$ & $\begin{array}{l}\text { In digital marketing, the } \\
\text { targeting is phenomenal as the } \\
\text { content is developed on the } \\
\text { basis of the target audience. } \\
\text { The advertisement is purely } \\
\text { based on particular buyers. }\end{array}$ \\
\hline Reach & $\begin{array}{l}\text { Market Reach is limited or } \\
\text { specific to a certain place. }\end{array}$ & $\begin{array}{l}\text { Anyone anywhere can be } \\
\text { reached in digital marketing. } \\
\text { The hashtag provides a greater } \\
\text { reach for marketers. }\end{array}$ \\
\hline Interruptions & $\begin{array}{l}\text { Interruption is high. It sometimes } \\
\text { makes customers irritate when } \\
\text { they receive calls from the } \\
\text { company during their work-life } \\
\text { (Dhote 2015). }\end{array}$ & $\begin{array}{l}\text { The interruption rate is low, } \\
\text { as here customer attention is } \\
\text { diverted through media } \\
\text { marketing. }\end{array}$ \\
\hline
\end{tabular}


International Journal of Social Science and Economic Research

ISSN: 2455-8834

Volume:06, Issue:07 "July 2021"

\begin{tabular}{|l|l|l|l|}
\hline Communication & $\begin{array}{l}\text { Indirect means of } \\
\text { communication. }\end{array}$ & $\begin{array}{l}\text { Direct communication with } \\
\text { the target audience. }\end{array}$ \\
\hline Trustworthiness & $\begin{array}{l}\text { Trustworthiness is high. It is } \\
\text { customers have faith or they } \\
\text { don't. }\end{array}$ & $\begin{array}{l}\text { It totally depends on the } \\
\text { feedback. Positive feedback } \\
\text { creates a good image whereas } \\
\text { negative feedback drives away } \\
\text { the client. Customers often } \\
\text { fear fraud over digital } \\
\text { marketing. }\end{array}$ \\
\hline Experience & $\begin{array}{l}\text { Marketing experience is quite } \\
\text { adventurous. There is a need to } \\
\text { go from one place to another } \\
\text { which has good experience for } \\
\text { the marketers }\end{array}$ & $\begin{array}{l}\text { In this type of marketing, the } \\
\text { marketer just needs to sit in } \\
\text { one place and do marketing by } \\
\text { own website on an online } \\
\text { basis. Sometimes it is boring } \\
\text { but it is time and money- } \\
\text { saving also. }\end{array}$ \\
\hline
\end{tabular}




\section{International Journal of Social Science and Economic Research}

ISSN: $2455-8834$

Volume:06, Issue:07 "July 2021"

\subsection{Findings}

So, from the above research, it is almost clear that the digital form of marketing is quite a costeffective approach. It allows marketing the desired product and service from anywhere and anytime. It is also beneficial for the environment as it saves paper which ultimately saves the trees. In traditional marketing, the communication is in indirect means wherein digital marketing the marketer can communicate directly with the targeted consumer. The digital form of marketing has made several new opportunities for technologically skilled people who can create new job areas for entrepreneurs, job finders, and researchers. To track new areas for marketing and to reach that place is quite difficult in the traditional approach of marketing as not every place has a suitable transport facility and moreover, there is the extra expenditure of transport also, while digital marketing makes it simple and everyone gets access to every area comfortably and it's affordable also. Research has shown that in the decision-making process, especially in the traditional marketing process, it is quite difficult due to the complexity in the research process of the market but in digital marketing, it is easier. However, the average value preferences of digital marketing are quite higher than the average value preferences of the traditional marketing approach as nowadays media gives more emphasis on the telecommunication industry. This research has covered thirteen aspects and gives data in the form of comparative analysis to establish the fact that digital marketing is the latest and easier form of a marketing approach than the traditional one.

\subsection{Conclusion}

The main motive of this research thesis is to clarify and search the dynamic inherent in marketing as a concept. In order to achieve this aim, the research focuses on traditional and digital marketing strategies which are applied by the business institutions to handle their products and services to the consumers. This investigation of traditional and digital marketing strategies enables a researcher to identify the benefits and downsides of two strategies through a concentrated focus on their approaches of marketing products and services to consumers. A perfect comparison between these two marketing strategies makes sure a researcher achieves his/ her goal by proving the appropriate answers to the appropriate research objective questions. The importance of these answers to the research questions is almost in a comprehensive manner which can be easily understood by the similarities, differences, and the impact of the concepts on the marketing goods and services. This research clears that the main function of the traditional marketing strategies and approaches is intangible. With the further growth of digital marketing which is supported by the findings and literature, There are of course so many advantages of converting to digital marketing, magazines and newspapers are slowly going digital. However, both the literature and findings agree that digital marketing methods have better targets than 
International Journal of Social Science and Economic Research

ISSN: 2455-8834

Volume:06, Issue:07 "July 2021"

traditional ones. But the literature is not discussing in a biased form, rather it maintains the aim to evaluate both the strategies in their way. Moreover, the literature and several findings are agreed to depend on both the processes according to the market needs. Therefore to choose one method of marketing should be dependent on the situation.

\section{References}

Bala, M., \& Verma, D. (2018). A critical review of digital marketing. M. Bala, D. Verma (2018). A Critical Review of Digital Marketing. International Journal of Management, IT \& Engineering, 8(10), 321-339.

Yasmin, A., Tasneem, S., \& Fatema, K. (2015). Effectiveness of digital marketing in the challenging age: An empirical study. International Journal of Management Science and Business Administration, 1(5), 69-80.

Todor, R. D. (2016). Blending traditional and digital marketing. Bulletin of the Transilvania University of Brasov. Economic Sciences. Series V, 9(1), 51.

Salehi, M., Mirzaei, H., Aghaei, M., \&Abyari, M. (2012). Dissimilarity of E-marketing VS traditional marketing. International journal of academic research in business and social sciences, 2(1), 510-515.

Mirzaei, H., Jaryani, E., Aghaei, M., Salehi, M., \&Saeidinia, M. (2012). Differences of "traditional marketing" in opposition to "electronic marketing". In 2012 International Conference on Economics, Business and Marketing Management (Vol. 29, pp. 231-234).

Bhayani, S., \&Vachhani, N. V. (2014). Internet marketing vs. traditional marketing: a comparative analysis. FIIB Business Review, 3(3), 53-63.

Mandal, P., \& Joshi, N. (2017). Understanding digital marketing strategy. International journal of scientific research and management, 5(6), 5428-5431.

Park, Y. S., Konge, L., \&Artino, A. R. (2020). The positivism paradigm of research. Academic Medicine, 95(5), 690-694.

Nicolas, C., Valenzuela-Fernández, L., \&Merigó, J. M. (2020). Research trends of marketing: A bibliometric study 1990-2017. Journal of Promotion Management, 26(5), 674-703.

Hammou, I., Aboudou, S., \&Makhlouf, Y. (2020). Social Media and Intangible Cultural Heritage for Digital Marketing Communication: Case of Marrakech Crafts. 
International Journal of Social Science and Economic Research

ISSN: 2455-8834

Volume:06, Issue:07 "July 2021"

Pandey, P., \& Pandey, M. M. (2021). Research Methodology Tools and Techniques.

Newman, M., \& Gough, D. (2020). Systematic reviews in educational research: Methodology, perspectives, and application. Systematic reviews in educational research, 3-22.

López García, J. J., Lizcano, D., Ramos, C. M., \& Matos, N. (2019). Digital marketing actions that achieve a better attraction and loyalty of users: An analytical study. Future Internet, 11(6), 130.

Gaitniece, E. (2018, September). Digital Marketing Performance Evaluation Methods. In CBU International Conference Proceedings (Vol. 6, pp. 135-140).

Melović, B., Jocović, M., Dabić, M., Vulić, T. B., \&Dudic, B. (2020). The impact of digital transformation and digital marketing on the brand promotion, positioning, and electronic business in Montenegro. Technology in Society, 63, 101425.

Kannan, P. K. (2017). Digital marketing: A framework, review, and research agenda. International Journal of Research in Marketing, 34(1), 22-45.

Dhote, T., Jog, Y., Gavade, N., \& Shrivastava, G. (2015). Effectiveness of digital marketing in education: An insight into consumer perceptions. Indian Journal of Science and Technology, 8(S4), 200-205. 